\title{
Det usynlige og det synlige
}

\section{Om at se det umiddelbart usynlige ved teknikkens hjælp \\ - og om ikke at se nok på det, man allerede kan se}

affotograf Mogens Bech, Det Kgl. Bibliotek,

kunsthistoriker Kira Kofoed, projektforsker, Thorvaldsens Museum,

klassisk arkeolog Kristine Bøggild Johannsen, museumsinsp., Thorvaldsens Museum \&

klassisk arkaolog Jan Stubbe Østergaard, fhv. forskningsinsp., Ny Carlsberg Glyptotek

\section{Multispektralt fotografi - en teknisk introduktion}

For ca. 6 år siden blev jeg for første gang gjort bekendt med multispektralt fotografi. Det skete ved en éndags forevisning på Statens Museum for Kunst. En langhåret ingeniør fra San Diego, Californien, havde opsat et Storm P.-lignende udstyr i museets store studie. Ingeniøren indledte med en lang forklaring om det usynlige lys, og som gammel fotograf undrede jeg mig over, hvad man uden dét kunne se. Kort efter slukkede han al lyset i studiet og tændte nogle mærkelige lamper med 'usynligt' lys. Vi stod i adskillige minutter i totalt mørke, mens eksponeringen foregik af et 1700-tals maleri. Kun en lille rød lysdiode på kameraet fortalte, at der blev eksponeret - og hvilken magi fremkom!

Men først lidt om teknikken og betydningen, for hvad betyder multispektralt? Ja, multi betyder flere, men flere hvad? Lys består af bølger, og hver farve har sin egen specifikke bølgehastighed. Det synlige lys, 'regnbuens farver', har en bølgefrekvens, der spænder fra ca. $380 \mathrm{~nm}$ (nanometer) til $750 \mathrm{~nm}$, dvs. fra dybeste violet over blå, gul og grøn til rød. Stråling med bølgelængder, der ligger lige under det synlige spektrum, kaldes ultraviolet lys (UV), mens stråling med bølgelængder lige over spektret kaldes infrarødt lys (IR). Multispektralt dxkker altså flere spektre end det synlige lys: det dækker også over UV og IR.

Alt lys er altså bølger, men bølger er også energi. Som det ses på nedenstående illustration har de forskellige farver forskellig energi. Vores grundfarver blå, grøn og rød er de energimæssigt kraftigste i normalt dagslys.

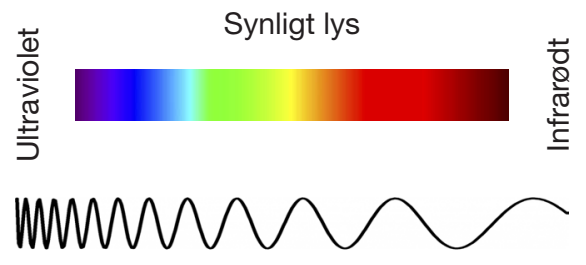

Ill. 1: Lysbolgernes variation set ift. de forskellige farvespektre.

Når det kommer til UV og IR, er energien derimod meget lille, og det var derfor, vi stod meget længe i mørke i Statens Museum for Kunsts studie. Vi ville nemlig kun fotografere med UV og IR. 


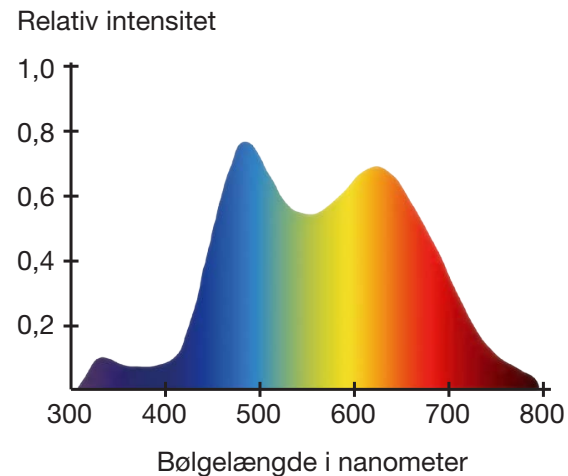

Ill. 2: Illustration afforskellen i energiintensitet for hbv. ultraviolet lys (under ca. $380 \mathrm{~nm}$ ), synligt lys (ca. 380-750 nm) og infrarodt lys (over ca. $750 \mathrm{~nm}$ ).

\section{Kameraet}

I dag kender alle det moderne, digitale kamera. Vi retter det mod motivet og trykker: fint billede. Men teknikken bagved er ikke så enkel. Faktisk ser kameraet ikke farver, men har et såkaldt charge-coupled device (CCD), som er følsomt over for energibølger i tre lag (dvs. tre spektre).

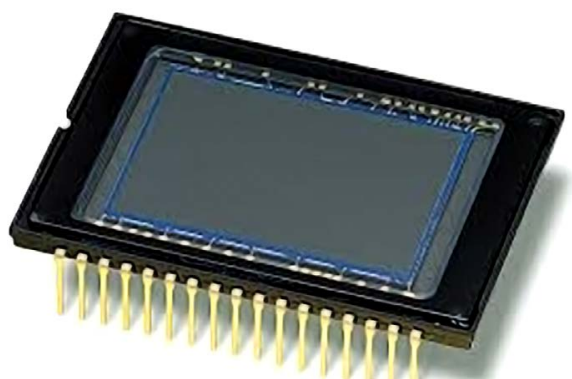

Ill. 3: Charge-Coupled device (CCD).

Man kalder det et akromatisk CCDkamera. Én måling tages for de grønne, én for de blå og én for de røde farver. Faktisk optager kameraet kun, hvor meget energi, der er i de tre lag (ca. 1/3 til hver farve

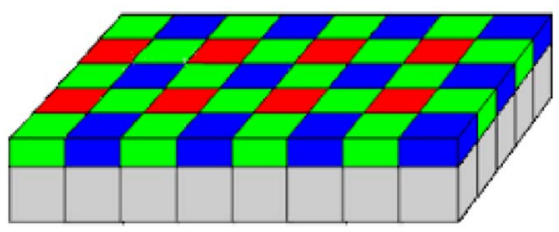

Ill. 4: Visualisering af en trespektret, akromatisk CCD-måling, der som slutresultat leverer en såkaldt RGB-fil (dvs. Red, Green, Blue-fil) og er velegnet til synligt lys.

med forskellig intensitet). Efterfølgende sammensætter kameraets computer energilagene til det synlige billede. Resultatet er en såkaldt RGB-fil. Disse flerfarvede optagelses-CCD'er kræver meget lys (energi) og er velegnede til synligt lys.

Ved UV- og IR-lys bruger vi i stedet en CCD, der er monokrom. Dvs., at den ikke opfatter de enkelte pixels på CCD'en som hhv. røde, grønne eller blå, men blot måler samtlige bølger på alle pixels. Dette giver en meget større lysfølsomhed, og den kan vi udnytte til det energimæssigt svage UV- og IR-lys. For at gøre det muligt 'kun' at optage de ønskede spektre på vores monokrome CCD, må vi adskille de områder, vi ønsker at måle energien i. Det vil med andre ord sige, at vi foran objektivet sætter forskellige filtre, som kun tillader, at lige præcis de 'skiver' af det samlede bølgeområde, som vi ønsker at analysere, kommer igennem.

Hvorfor så anvende IR- og UV-fotografering? Alle grundmaterialer reflekterer lys på helt specifikke måder. Med andre ord kan vi udvælge, at vi kun vil se de røde farver ved at filtrere alle andre spektre fra i de omkringliggende områder. Det er præcist dette, man udnytter i multispektralt fotografi. I det indledende eksempel 


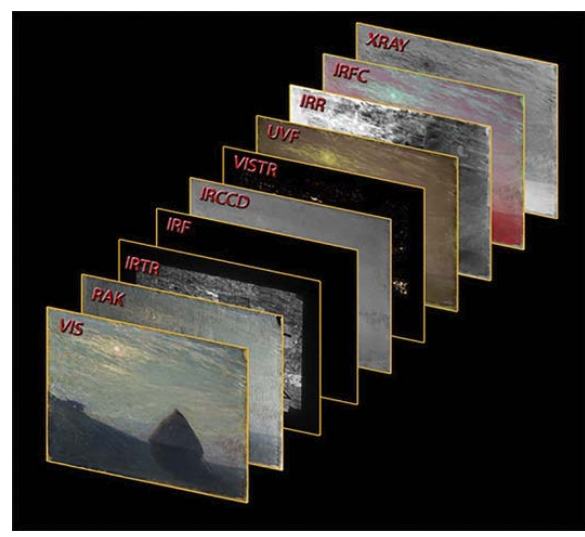

Ill. 5 Illustrationen viser det samme motiv optaget med 10 forskellige filtre. Farverne pa de enkelte filer er tilfojet efter optagelse for at anskueliggøre de enkelte filtres måleområde.

fra Statens Museum for Kunst, optog vi en UV-sekvens, hvor kulstof netop reflekterer mest på bølgerne under 350 $\mathrm{nm}$, og så fremkom magien: et nyt billede nedenunder det umiddelbart synlige! En kultegning under det færdige billede; et forarbejde, der var blevet overmalet med farver, og derfor var væk for øjets synlige spektre.

\section{Hvad er der siden sket?}

Den føromtalte ingeniør, Ken Boydston, har jeg siden mødt ved flere konferencer og et enkeltmands-kursus på Library of Congress i Washington DC (LOC). Der diskuterede vi udviklingen - hvor skal vi hen med multispektralt fotografi? Ken Boydston har i dag et firma, som leverer et fuldt færdigt set up med kamera og lyskilder. Han er en sand guru på området. Specielt på lyskildeområdet er der sket enorme fremskridt. Vi har i dag LED-lys, der kan begrænses til kun at udsende lys (energibølger) i afgrænsede spektre. Vi har fået endnu mere følsomme monokro- me CCD'er, og flere biblioteker og museer har fàet øjnene op for mulighederne i multispektralt fotografi. Materialeanalyse er blevet en stor del af fotografens arbejde, ja sågar evnen til at se vandmærker på grund af højdeforskellen i dokumenter har han/vi eksperimenteret med. Alle analyser foretages under mottoet non invasive, dvs. uden fysisk indgreb $\mathrm{i}$ materialet. Konkret har vi her på KB fået lavet analyser af dokumenter, der var nærmest ulæselige på grund af f.eks. brand, ældning og vandskader. Alle er ved hjælp af sammensætning af forskellige spektre gjort læsbare. Softwaren, som analyserer billederne, er også udviklet meget siden mit første møde med teknologien, og her må Fenella France fra LOC også fremhæves som den bærende kraft. Hun har videreudviklet den tekniske arbejdsgang, så de enkelte lag (energilag) simpelt kan sammensættes og ny magi opstå.

$\mathrm{KB}$ rådede ikke over dette udstyr, så det var med en vis nervøsitet, at jeg sagde ja til at undersøge et kobberstik fra Thorvaldsens Museum, som havde nogle svagt synlige blyantspåtegninger. Jeg lånte de kraftigste UV lamper, jeg kunne fremskaffe i København, og mørklagde atelieret på KB. Jeg lavede diverse optagelser og lagde de forskellige lag sammen, og pludselig var der læsbarhed (ill. 6 og 7). ${ }^{1}$

\section{Multispektrale perspektiver og fremti-} dige samarbejder

Der er på KB’s initiativ oprettet en gruppe med en fælles interesse i multispektralt fotografi. De største museer, politiet, universitetet og biblioteker i København og Århus er med i gruppen. Derudover er der løbende kontakt med næsten alle, der har købt udstyret i udlandet. Når udstyret er indkøbt til KB, vil en international 


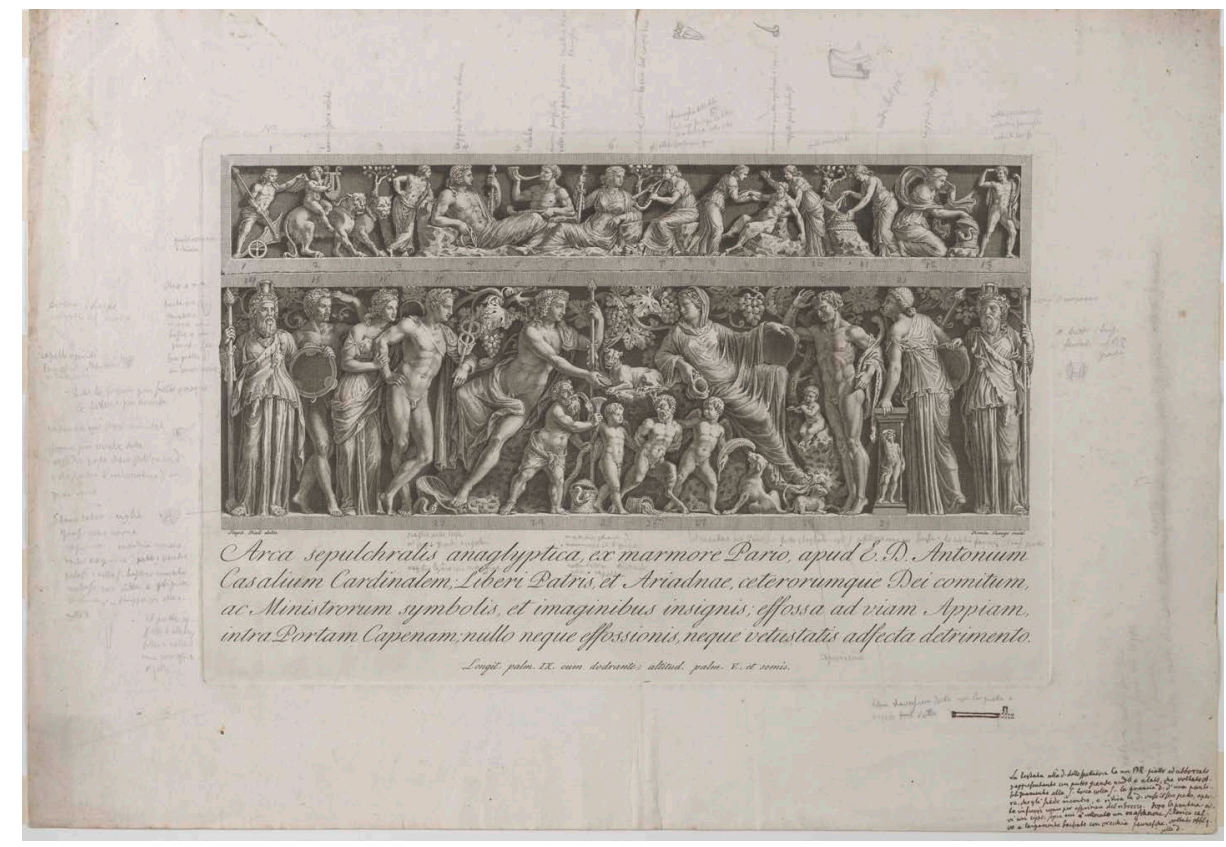

Ill. 6 Domenigo Cunego: Casali-sarkofagen med Dionysos og Ariadne. Kobberstik, udfort 1777 efter tegnet forleg af Stefano Piale, $299 \times 464 \mathrm{~mm}$. Thorvaldsens Museum, inv.nr. E1456. Original ved almindeligt lys.

netværksgruppe blive inddraget, så der kan udveksles erfaringer om arbejdsgange og de forskellige materialetyper. At kunne opsamle viden på tværs af museer, institutter og institutioner i en fælles database, og med et fælles mobilt udstyr, som man kunne låne eller leje sig ind på, ville utvivlsomt højne kvaliteten af forskningsresultaterne og give helt nye muligheder for formidling af vores fælles kulturarv.

I Cunego-kobberstikkets tilfælde blev utydelig tekst mere læselig og transskriptionen kunne forbedres. Det har efterfølgende vist sig, at for Thorvaldsens Museum er teknikken desuden yderst øjenåbnende og anvendelig på Thorvaldsens tegninger - $\mathrm{i}$ særdeleshed dem, der indeholder både grafit og blæk. Under et studiebesøg hos firmaet Videometer A/S i Hørsholm² i september blev forskellige typer dokumenter og tegninger analyseret multispektralt. De mest overbevisende resultater opstod, når en undertegning, udført med grafit, kunne isoleres fra det øvre afsluttende lag, påført med blæk af Thorvaldsen for at fiksere den endelige udgave af tegningen. Denne mulighed for at kigge ned igennem tegningslagene giver os en enestående mulighed for at følge Thorvaldsens tegneproces på helt tæt hold. En mulighed, der ikke blot giver en større konkret faglig viden om billedhuggerens teknik og motivudvikling, men også kan udfoldes i regi af både skoletjeneste og bredere formidlingstil- 

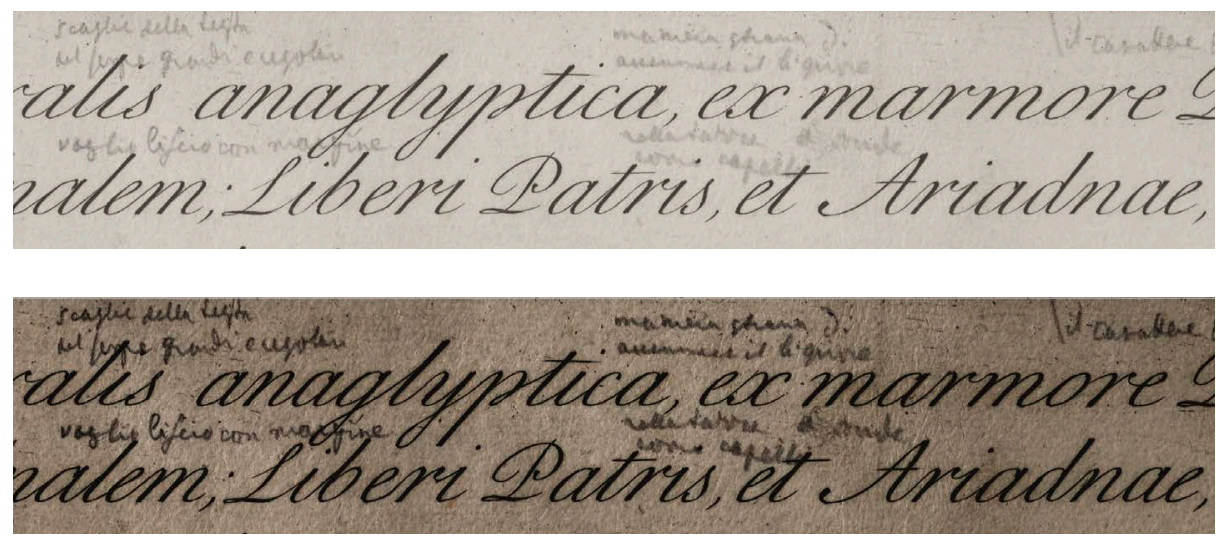

Ill. 7 (øverst): Udsnit ved almindeligt lys; Ill. 8 (nederst): Udsnit ved multispektralt lys.

tag. Undersøgelser af malerier for f.eks. underliggende signaturer og undertegninger, af gipsmodeller ift. værkstedsspor gemt under eftertidens skidt, og af skrøbelige genstande, der ikke tåler at blive udstillet, rummer også stort potentiale for fremtidige undersøgelser og øjenåbnende formidling.

\section{Om kobberstikket fra Thorvaldsens Museum og om forbindelsen tilbage til KB's samlinger}

Den romerske sarkofag, hvis reliefprydede forside kobberstikket gengiver, blev fundet i 1775 ved Via Appia Antica i Rom under den højtstående prælat og senere kardinal Antonio Casalis (1715-1787) vinmark inden for Porta S. Sebastiano i den aurelianske bymur. Casali var en passioneret antiksamler, og sarkofagen blev et pragtstykke i hans samling, der hovedsageligt befandt sig på hans landsted, Villa Casali, på Monte Celio i Rom.

Stikket af 'Casali-sarkofagen' blev udført af kobberstikkeren Domenico
Cunego (1727-1803) ud fra Stefano Piales (1753-1809) tegning, der igen må være lavet foran den antikke original. Der er altså to 'oversættelsesled' fra original til kobberstik. Både tegning og stik blev fremstillet på Casalis initiativ, og Cunegos stik kan dateres til 1777 takket være en omtale i det romerske ugeblad Diario di Roma i maj måned dette år. ${ }^{3}$

Cunegos stik optræder imidlertid også i et imposant bogværk i folioformat om en af Vatikanets store kunstsamlinger, Museo Pio-Clementino. ${ }^{4}$ Selvom Casalisarkofagen ikke var en del af samlingen, kom den med i et tillæg til udgivelsens femte bind. Det skyldtes vel dels dens enestående bevaringsmæssige tilstand og rige udsmykning, dels nok også ejerens tætte personlige relation til de regerende paver, der havde modtaget flere antikke genstande af Casali.

Den danske billedhugger Bertel Thorvaldsen (1770-1844) ejede de seks første bind af Pio-Clementino-udgivelsen, som stadig findes i hans bogsamling på Thorvaldsens Museum. Men derud- 
over findes kobberstikket af Casali-sarkofagen også i billedhuggerens grafiksamling som løsark - forsynet med den danske arkæolog og numismatiker Georg Zoëgas (1755-1809) påskrifter. Det er dette stik, der er blevet underkastet multispektral fotografering med henblik på en tydeliggørelse af påskrifterne.

\section{Stikkets vej til Thorvaldsens Museum}

Vi kan kun gisne om, hvordan Cunegos stik som løsark er endt i Thorvaldsens Museum. Et velkvalificeret bud er dog, at stikket ligesom en række andre kobberstik, tegninger, bøger, afstøbninger m.v. er kommet $\mathrm{i}$ Thorvaldsens besiddelse $\mathrm{i}$ forbindelse med opgørelsen af boet efter Zoëga. ${ }^{5}$

Da Zoëga døde i 1809, var han omgivet af sine nærmeste, heriblandt Thorvaldsen, som ifølge samtidige beretninger ikke veg fra sin nære ven og mentors side i hans sidste tid. ${ }^{6}$ Det var således også naturligt, at Thorvaldsen blev tildelt rollen som den ene af de to bestyrere af dødsboet. ${ }^{7}$ Fra en række bevarede breve og samtidige beretninger er det muligt at tegne et billede af forløbet, men vi mangler stadig vigtige brikker. Af kilderne fremgår det, at Thorvaldsen og boets anden bestyrer, den dansk-norske rigmand og skønånd John 'Baron' Brown (1738-1821), i tiden umiddelbart efter dødsfaldet søgte at sikre eventuelle værdigenstande i boet for at tilgodese Zoëgas tre børn. Zoëgas uvurderlige manuskripter blev derfor forseglet $i$ et skrin og bragt i sikkerhed hos deres fælles veninde, Caroline von Humboldt (1766-1829), mens en uventet stor pengesum (knap 3500 Scudi) blev deponeret hos en bankier. For at danne sig et overblik over manuskrip- terne med henblik på senere at kunne tilbyde dem til KB blev den unge danske filolog Georg Koës (1782-1811) bedt om at udarbejde en detaljeret oversigt over dokumenterne, mens det tilfaldt Humboldt, Brown, Thorvaldsen selv m.fl. at gennemgå den efterladte korrespondance. Efter alt at dømme fandt denne gennemgang af dokumenterne sted i Thorvaldsens lejlighed. Det er imidlertid påfaldende, at hverken Koës' registrant eller de senere publicerede oversigter over materialet nævner det store ledsagende billedmateriales skæbne. ${ }^{8}$ Ganske vist efterspurgte den tyske filolog og elev af Zoëga, F.G. Welcker (1784-1868), i sin biografi fra 1819 de tegninger, som han vidste, var blevet udført til det upublicerede manuskript om amuletterne i kardinal Stefano Borgias (1731-1804) samling samt kobberstik af relieffer med gengivelse af den græskxgyptiske gud Harpokrates og af tolv etruskiske 'offerskåle' (egentlig spejle), som han ligeledes vidste, var udført. ${ }^{9}$ Hvorvidt årsagen til den manglende omtale af billedmaterialet skyldes, at Koës og Welcker ikke kendte til dets eksistens eller ikke anså det for vigtigt, må henstå i det uvisse.

Det har længe været kendt, at et mindre antal genstande fra boet efter Zoëga, særligt bøger med dedikation, var indgået i Thorvaldsens Museum. ${ }^{10}$ Men at det store billedmateriale, som ledsagede Zoëgas manuskripter og breve, også var indgået i museet, var ukendt indtil for ganske nylig. Med publiceringen af Zoëgas breve i 2015 blev det imidlertid muligt at stille nye spørgsmål til materialet. Thorvaldsens Museums store samling af tegninger og kobberstik af xgyptiske værker har længe givet anled- 
ning til undren. Ganske vist opbyggede Thorvaldsen i løbet af sit mangeårige ophold i Rom en betragtelig samling af xgyptiske oldsager, men billedmaterialet - som i mange tilfælde bærer håndskrevne kommentarer med en anden hånd - har alligevel en helt anden karakter. Ved at sammenligne dette materiale med Zoëgas breve, som stadig findes på KB, stod det hurtigt klart, at der var tale om oprindelig vedlagte illustrationer, og at de håndskrevne kommentarer i mange tilfælde skyldes Zoëga. Indtil videre er 427 værker fra boet identificeret i Thorvaldsens samlinger, men der er formentlig tale om langt flere. Særlig interessant er prøvetrykkene til udgivelsen af de xgyptiske monumenter i Museo Naniano i Venedig, Monumenta Artis Agyptice in Musao Naniano Venetiis (1778), som findes i to versioner i museets samlinger: Én hvor Zoëga i hånden har indført kommentarer til de enkelte værker og en senere version, hvor de samme kommentarer er trykt som forklaring under illustrationerne. Eksemplerne viser ikke blot Zoëgas videnskabelige tilgang til værkerne, men også den vægt, han tillagde præcise illustrationer. Og det er oplagt at sammenligne kommenteringen af de ægyptiske monumenter med den, vi finder på Cunegos stik.

\section{Med værket som udgangspunkt - et grundprincip for Zoëga}

En af de allervigtigste opgaver, hvis ikke dén vigtigste, for både kunsthistorikere og arkæologer er at betragte de konkrete værker og genstande, når de skal beskrives, forstås og formidles. Selv i fotografiets, virtual realitys og 3D-scanningens tidsaldre er der ingen vej uden om de fysiske værker: Samspillet mellem talrige

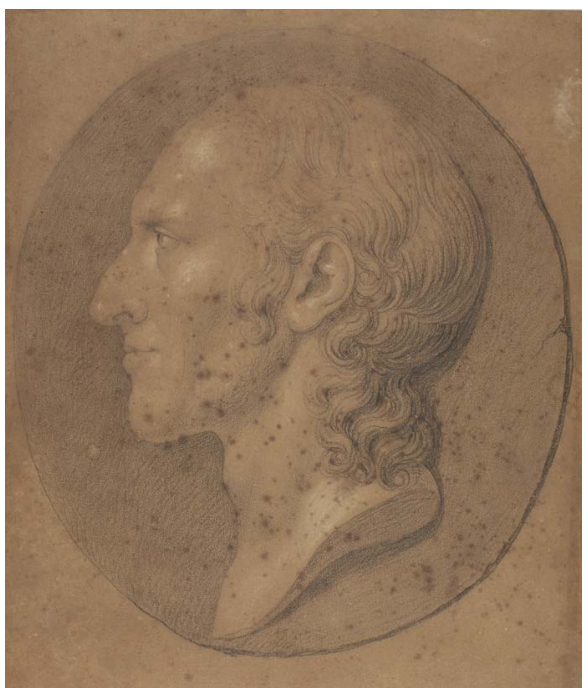

Ill. 9 Bertel Thorvaldsens tegnede portret af Georg Zoëga, sort og hvidt kridt på brunt papir, $258 \times 208 \mathrm{~mm}$. Thorvaldsens $\mathrm{Mu}$ seum, inv.nr. C761r. Tegningen er formentlig anvendt eller direkte udfort som forleg til det sidste kobberstik i Zoëgas hovedvark $\mathrm{Li}$ bassirilievi antichi di Roma, vol. III, Rom 1808-1809. I andre udgaver af bogverket findes portrettet gengivet $i$ vol. II, tavle mellemp. 306 og 307.

synsvinkler, oplevelsen af stoflighed og af værket i skiftende belysning, fornemmelsen af fysiske størrelsesforhold mv. er stadig afgørende for den grundige og videnskabeligt lødige betragtning. Et overordnet indtryk af en genstand kan selvsagt opnås på grundlag af en reproduktion - f.eks. en tegning, et fotografi eller - som i vores tilfælde - et kobberstik, men gengivelserne er sjældent fuldt ud retvisende. Zoëgas påskrifter på kobberstikket af Casali-sarkofagens låg og forside vidner med al tydelighed om hans prægnante fokus på dette springende punkt. Han skriver bl.a.: 
"il carrattere del Panisco tutto sbagliato"

[den lille pan-figurs udtryk er aldeles forfejlet].

"tutte le figure piu svelte e magre" [samtlige figurer er slankere og tyndere]

Konstateringerne, som blot er to blandt mange tilsvarende i margin på kobberstikket, er sigende for de oversættelsesproblemer, der altid vil opstå, når ét medie omsættes til et andet. Kobberstikket af Casali-sarkofagen er nemlig et eksempel på en reproduktion, der rummer adskillige afvigelser fra originalen.

For Zoëga var reproduktionen så misvisende ift. originalværket, at han ud over kommentarerne på selve stikket yderligere nedskrev to fulde sider med om afvigelserne mellem værk og reproduktion. Det gjorde han ikke blot ift. stikket af Casali-sarkofagen, men til hovedparten af de kobberstik, der blev udgivet i den første udgave af kataloget over Museo Pio-Clementinos samlinger. ${ }^{11}$ Kommentarerne findes ligesom Zoëgas breve og manuskripter på KB. ${ }^{12}$ Som notaterne på Cunegos kobberstik er noterne på KB suppleret med små tegnede detailstudier af bl.a. en sandals udseende, en silens særprægede penis, et skægs præcise facon og detaljerne i et antikt musikinstrument.

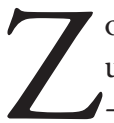

oëgas tanke var oprindeligt at udgive kommentarerne samlet - uden yderligere illustrationer alene for at gøre opmærksom på kobberstikkenes ringe sandhedsværdi ift. de antikke værkers faktiske udseende. ${ }^{13} \mathrm{Han}$ ændrede imidlertid mening og besluttede sig for, mere pædagogisk, at udgive en kommenteret og ny-illustreret serie om samtlige antikke relieffer i Rom. Men ved sin død i 1809, havde han 'kun' nået at fuldføre en mindre del af det omfattende projekt. De første tre bind af serien $L i$ bassirilievi antichi di Roma udkom året forinden, og de omhandlede alene reliefferne i Villa Albani og Palazzo Albani i Rom. ${ }^{14}$ Relieffet på Casali-sarkofagen er derfor ikke omtalt i værket, men i sit forord beskriver Zoëga klart sin intention om at åbne sin samtids blik for en mere ren og videnskabeligt funderet antik-opfattelse. ${ }^{15}$ Middelalderens mørklægning af antikken og de moderne reproduktioners forvanskninger af motiverne skulle erstattes af en langt mere værkorienteret og grundig undersøgelse og formidling. Han sammenligner i sit forord kunstforskningen med numismatikken, der pga. mønternes beskedne og let håndterlige format havde bevaret den, i hans øjne, helt afgørende direkte relation mellem betragter og genstand. Inden for kunstens tunge, geografisk spredte og svært tilgængelige genstandsfelt var en mere ufortolket tilgang og formidling derimod en forudsætning for videnskabelighed. Og selvom opgaven var besværlig, påtog Zoega sig den med stor entusiasme: "Jeg er nu tutto bassorilievo", skrev han i 1807 begejstret til sin gode ven, teologiprofessor, arkæo$\log$ og senere biskop Friedrich Münter (1761-1830) og uddybede i samme brev, i hvor høj grad illustrationernes præcision var afgørende:

“[...] besværligt falder det i denne Aarstiid at besøge snart eet snart et andet af de langtadspredte Museer og Paladser, som derved er uomgängligt, da jeg ej forlader mig hverken på andres eller på mine egne äldere Observationer. 


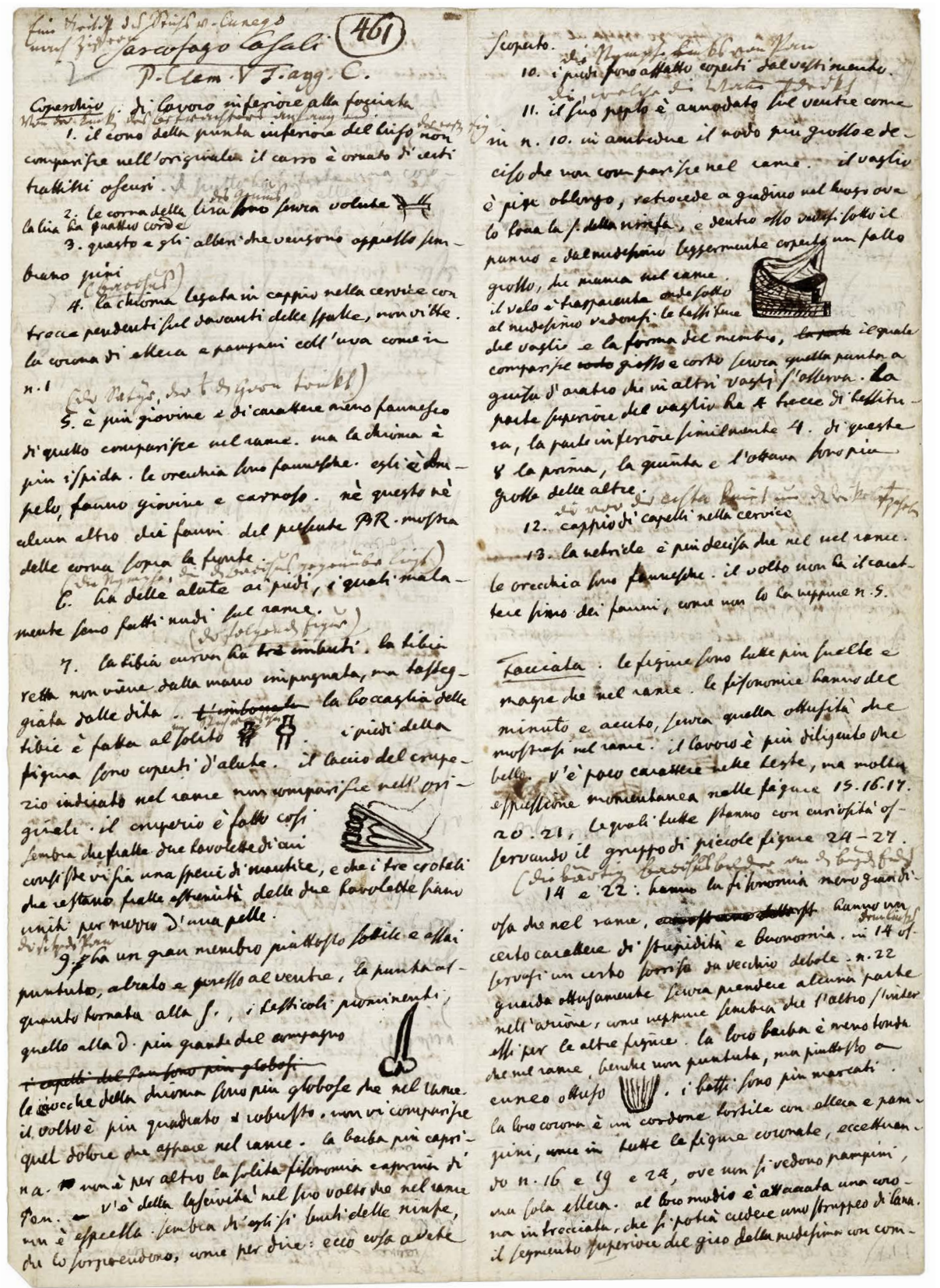

Ill. 10 Georg Zoëgas noter til Casali-sarkofagen, Händskriftsafdelingen, KB, NKS 357 b folio. Kasse: VII, ark merket '461'. 
Correctionen af Tegningerne og Kobberstikkene er det ubehageligste af alt, medens disse Artister ei kan finde sig deri at jeg som Lærd blander mig i hvad de ansee som deres exclusive. [...]

Piroli staaer for Tegningerne og Kobberne, jeg [...] har tillige forbeholdt mig [...] Opsyn med Kobberne i Henseende til deres Accuratesse. $[\ldots]^{\prime \prime 16}$

Cunegos kobberstik i Thorvaldsens grafiksamling er altså et skoleeksempel på Zoëgas metode og intention. Han har tydeligvis siddet med stikket over for den fysiske sarkofag og under samme eller et senere besøg i Casalis samling skrevet de to siders noter, der i dag findes på KB.

I 1818 udgav Welcker Zoëgas noter om sarkofagen og andre værker illustreret i den første udgave af Museo PioClementino, nogenlunde som de først var tænkt - dvs. som ren tekst og uden illustrationer. ${ }^{17}$ Men siden synes Zoëgas udførlige noteapparat at være stort set glemt igen. Den foreløbige gennemgang af manuskriptet vedr. de antikke relieffer antyder, at det direkte forhold mellem billedmateriale i Thorvaldsens Museum og noter i Zoëga-materialet på KB ikke er et enestående tilfælde. Derimod må vi forestille os, at en systematisk gennemgang af materialet - ligesom i tilfældet med Zoëgas breve - på afgørende vis både vil kunne bidrage til at fastslå billedmaterialets herkomst og samtidig give nye perspektiver på Zoëgas metode.

\section{Glyptoteket og 'Casali-sarkofagens' farver}

For Glyptoteket var det lidt af en åbenbaring at få kendskab til kobberstikket med Zoëgas påskrifter. Sarkofagen står jo nemlig nu i museet som en af kronjuvelerne i den romerske samling. Stikket føjede et interessant aspekt til værkets 'biografi', og kunne desuden, måske, kaste lys på en egenskab af særlig interesse: Farvesporene på reliefferne.

Takket være spektralfotograferingen på KB ved vi nu med sikkerhed, at de ikke nævnes hverken i Zoëgas påtegninger på stikket eller i noterne på KB. Hverken han eller nogen anden iagttager havde, inden sarkofagen kom til Glyptoteket, noteret sig, at reliefferne oprindeligt havde været farverige. At vide dét er en forskningshistorisk gevinst: Blindhed over for det, man ikke forventer at se, rammer selv de mest skarpsynede, dengang som nu.

\section{Casali-samlingens opløsning}

Italiens samling var en langstrakt proces, men de kongelige italienske troppers indtagelse af Rom i september 1871 var et afgørende øjeblik. Byen blev udråbt til den nye stats hovedstad med hektisk byggeaktivitet til følge, herunder et statsligt militærhospital. I 1880 blev en del af Villa Casalis areal eksproprieret til opførelsen af hospitalet, og i $1884 \mathrm{blev}$ det villaens tur.

Casali-samlingens sidste og barnløse ejer var Monsignore Giovanni Battista Casali-Del Drago (1838-1908). Han havde set skriften på væggen og påbegyndte så med rettidig omhu afhændelsen af de bedste antikker - med blik for realiteterne: Til en stat hører myndigheder, herunder nogle med ansvar for kunst og kulturarv under en relevant lovgivning. Da Casali-samlingen kom på markedet og helt frem til 1909 var det stadig Pavestatens gamle Editto Pacca fra 1820, der var gældende lov. Antikke kunstværker af fremragende kvalitet 


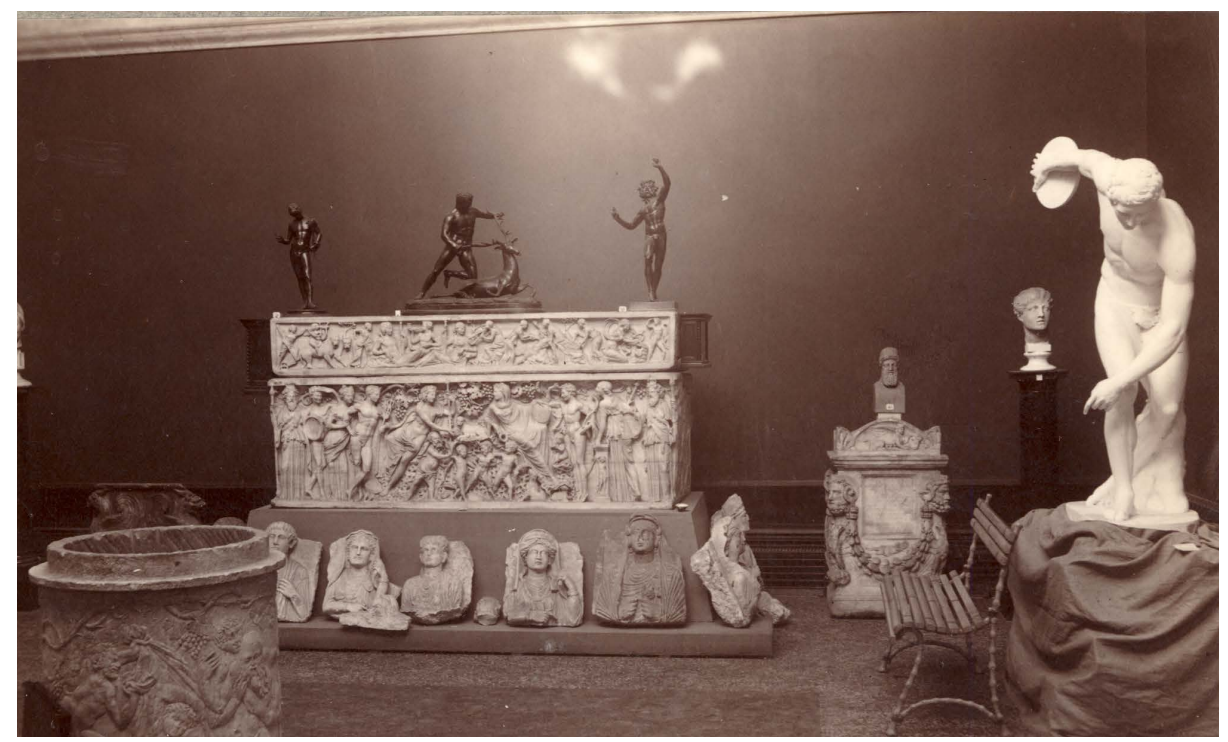

Ill. 11 'Casali-sarkofagen’ opstillet i Glyptotheket på Ny Carlsberg. 1883. Arkivfoto, Ny Carlsberg Glyptotek

havde national interesse og kunne ikke uden videre udføres, så det gjaldt for ejerne om at gå under myndighedernes radar og opnå højere priser ved salg ad så diskrete kanaler som muligt. Diskretionens adelsmærke er tavshed, og spekulationer er derfor dens følgesvend - dét mærkes i skildringen i det følgende af Casali-sarkofagens videre skæbne. ${ }^{18}$

\section{Carl Jacobsens køb af sarkofagen}

Den 1. marts 1883 sendte den norske klassiske arkæolog Ingvald Undset (18531893) et brev fra Rom til København. ${ }^{19}$ Modtageren var Ludvig Müller (18091891), direktør for Nationalmuseets Antiksamling og Thorvaldsens Museums første inspektør; Undset boede som stipendiat på det Tyske Arkæologiske Institut oppe på Capitol-højen. Brevets ærinde var at berette om en romersk sarkofag til salg hos kunsthandleren Saturnino Innocenti. Undset havde fra Müllers søn Sophus (1846-1934) hørt, at brygger Carl Jacobsen kunne være interesseret $\mathrm{i}$ at erhverve antik kunst: og nu var der så en mulighed, et enestående værk, "fundet for nylig nær Rom”. Man kan næsten ikke undgå at spekulere over, hvem der mon gav Undset et praj om sarkofagen. Kunne det være den tyske klassiske arkæolog Wolfgang Helbig, ansat ved det tyske institut og bosat i Rom siden 1860'erne? Det var i hvert fald ham, der fra $1887 \mathrm{og}$ frem var brygger Jacobsens agent i Rom. ${ }^{20}$

Derefter udviklede sagen sig hastigt takket være datidens effektive post- og telegrafvæsen. Ludvig Müller adviserede straks Jacobsen, og den 7. marts fik Undset brev fra bryggeren, samt, før det, et telegram fra samme om hans interesse for sarkofagen. Inden da havde Undset 


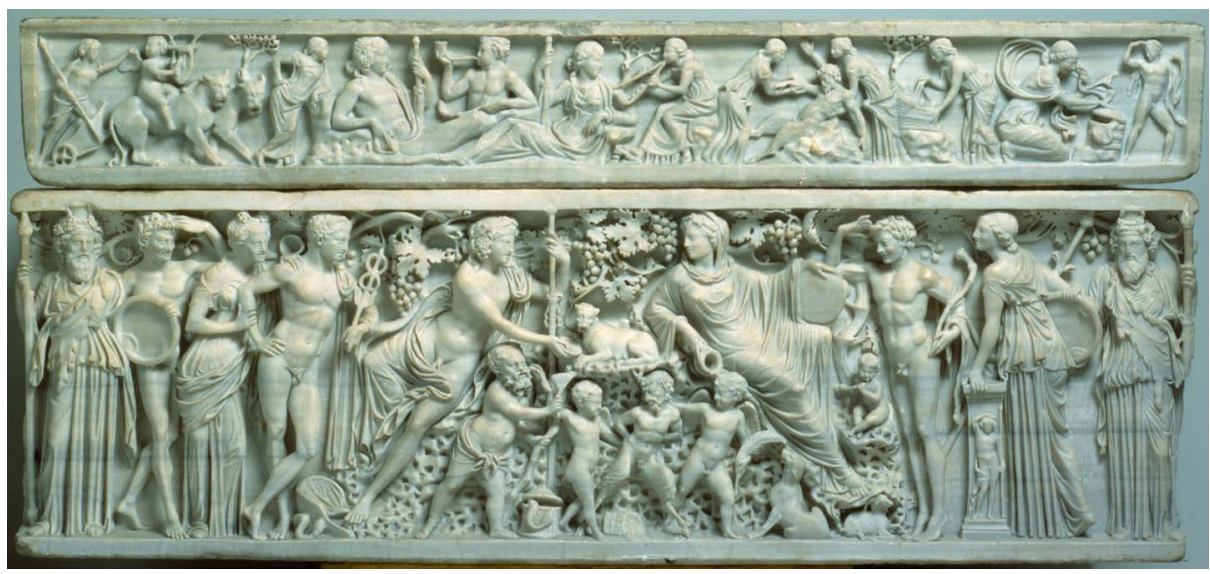

Ill. 12 'Casali-sarkofagen': Dionysos og Ariadne med folge. Rom, ca. 200 e.v.t. H. 68 cm, langde $222 \mathrm{~cm}$, bredde $83 \mathrm{~cm}$. Bemalet marmor. Ny Carlsberg Glyptotek IN 843. Museumsfoto, Ole Haupt.

opsøgt maleren m.m. Pietro Krohn (1840-1905) og kunsthistorikeren Julius Lange (1838-1896), der var i Rom for, på Jacobsens vegne, at erhverve et maleri til hans samling. De to anbefalede købet af sarkofagen, og d. 14. marts blev kontrakten underskrevet. Forsendelsen skete i to forseglede kasser udført af det samme firma, som i sin tid havde stået for nedpakningen af Thorvaldsens skulpturer. D. 14. april afgik sarkofagen med tog til Lübeck via München. Turen videre til København foregik med fragtskib, og endelig kunne sarkofagen opstilles i en tilbygning til Jacobsens villa i Valby. ${ }^{21}$

Længe inden da havde Undset i et brev af 13. marts oplyst Carl Jacobsen om, at sarkofagen bestemt ikke var fundet for nylig, men tværtimod var aldeles berømt. Han henviste til nogle af de publikationer, der nævnes andetsteds i denne artikel, herunder kobberstikket i Viscontis udgivelse af Museo Pio-Clementino.
Farvesporene ses, glemmes og genfindes Før sarkofagens indlemmelse i Jacobsens samling havde ingen, som nævnt, på skrift bemærket eksistensen af farvespor. De ses ellers med det blotte øje (Ill. X). Men Carl Jacobsen var en uhildet amatør og blev måske af den grund den første, der så og i korthed beskrev sarkofagens farver, nemlig i sin vejledning for de besøgende i Glyptotheket på $N y$ Carlsberg fra efteråret 1883. Om lågets relief skriver han: "På dette basrelief er der spor af farve. Vannus og cista mystica have været rødmalede og flere af figurernes øine bære spor af sort maling" 22 Bryggerens interesse for polykromien - de mange farver - i antik skulptur forblev usvækket, men der skulle gå lang tid, før sporene igen blev nævnt i faglitteraturen.

De omtales ikke i Frederik Poulsens katalog over Glyptotekets antikke skulpturer og ej heller i det relevante bind af den monumentale, internationale udgivelse af de romerske sarkofagrelieffer. ${ }^{23} \mathrm{Al}$ - 


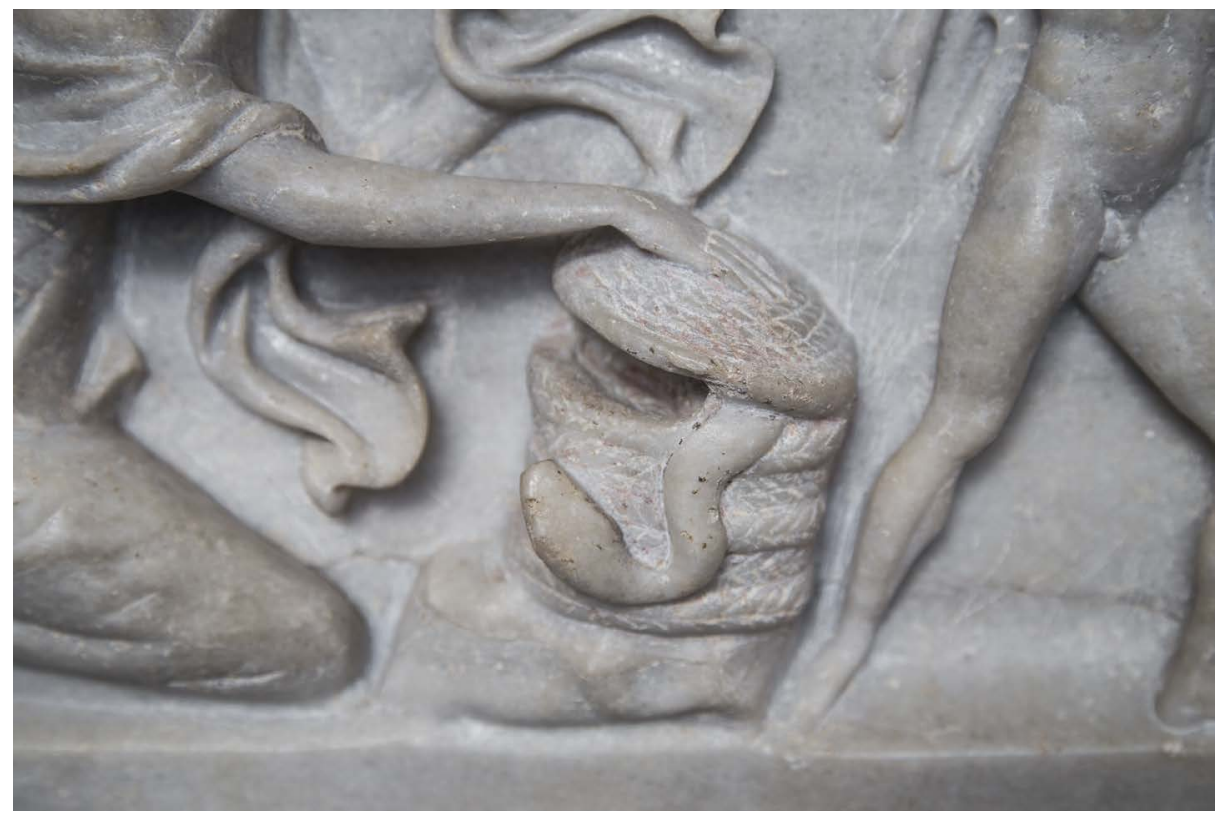

Ill. 13 'Casali-sarkofagen': Udsnit af lag relieffet med farvespor. Museumsfoto. Ana Cecilia Gonzales.

lerede i 1933 var der ellers blevet skrevet om farvesporene på romerske sarkofager i Museo Nazionale Romano i Rom, blandt dem en tvilling til Casali-sarkofagen. ${ }^{24}$

At farvesporene ikke ligefrem faldt i øjnene kan skyldes, at reliefferne for det første var temmelig beskidte og for det andet, at værket i mange år stod i modlys $i$ et gennemgangsrum mellem Vinterhaven og den antikke samling. Snavset blev fjernet i forbindelse med museets store katalogprojekt (1991-2017), for det havde som en af sine utallige sidegevinster, at der skulle ny-fotografering til. Under rengøring med destilleret vand gennem dyser med lavt tryk blev der ikke taget særligt hensyn til Casali-sarkofagens farvespor - fordi der ingen bevidsthed var om deres eksistens. Og de kan ikke ses i farvefotografiet i kataloget, men blev dog i det mindste nævnt. ${ }^{25}$

I mellemtiden var museets sans for farvernes betydning skærpet i takt med den faglige omverdens. ${ }^{26}$ Det førte til et tværfagligt forskningsprojekt 'På sporet af farven' (2009-2016), finansieret af museets egne midler og med fondsstøtte. ${ }^{27} \mathrm{Et}$ udvalg af græske og romerske skulpturer i museets samling blev undersøgt, herunder 'Casali-sarkofagen'. Takket være hele denne indsats ved vi nu, at reliefferne var fuldstændigt bemalede. ${ }^{28}$ Denne bemalings nærmere beskaffenhed vil kun fremtidige undersøgelser kunne afsløre. Det vil nok glæde Georg Zoëga i hans himmel, at vi følger $\mathrm{i}$ hans fodspor. 


\section{Noter}

1 Kamera: PhaseOne iXR kamera, med 60 $\mathrm{mB}$ bagstykke, Schneider $120 \mathrm{~mm}$ Macro linse Lys. Henzel flashys + UV lamper. Software: CaptureOne + Photoshop.

2 Stor tak til teknisk direktør og ph.d. Jens Michael Carstensen og til ph.d. Hildur Einarsdottir for hjælpsomhed og imødekommenhed i forbindelse med vores besøg.

3 Diario di Roma (også kaldet Cracas) dateret 3.5.1777. I udgaven dateret 3.2.1776 omtales fundet af sarkofagen, jf. R. Santolini Giordano: "Antichità Casali. La collezione di Villa Casali a Roma”. Studi Miscellanei 27, Rom 1989, 65.

4 G. Visconti \& E.Q. Visconti: Il Museo PioClementino, I-VII, Rom 1782-1807. Illustrationen af Casali-sarkofagen optræder som planche 'C' i femte bind. Syvende og sidste bind udkom dog først 1807 under G.B.A. Viscontis redaktion.

5 K. Bøggild Johannsen: "Relics of a Friendship. Objects from Georg Zoëga’s Estate in Thorvaldsens Museum", i: K. Ascani, P. Buzi, D. Picchi (ed.): The Forgotten Scholar: Georg Zoëga (1755-1809), Leiden 2015, 25-35.

6 Thorvaldsen tog Zoëgas dødsmaske (Thorvaldsens Museum, inv. nr. L653) umiddelbart efter døden indtraf, hvilket vidner om hans tilstedeværelse ved dødslejet. Jf. også Zoëgas læge, Heinrich Kohlrauschs (1777-1826), beskrivelse af sygdomsforløbet, i: Ø. Andreassen, K. Ascani (ed.): Georg Zoëga. Briefe und Dokumente, V, 2015, brev nr. 1265; N. Schow: En Beretning om afdöde Professor og Ridder Georg Zoega's Liv og Fortienester, iser med Hensyn til aldre Litteratur, Archeologie og afbildene Kunster, 1809, 62-63.

7 Om Thorvaldsens rolle, jf. Schow: Beretning om afdöde, 62; F.G. Welcker: Zoegas Leben. Sammlung seiner Briefe und Beurtheilung seiner Werke, II, Stuttgart \& Tübingen 417; J.M. Thiele: Thorvaldsen i Rom. 1805-1809, I, 1851, 120; Bøggild

Johannsen: Relics.

8 I. Boserup: "Georg Koës and Zoëga's Manuscripts Preserved in The Royal Library in Copenhagen", i: K. Ascani, P. Buzi, D. Picchi (ed.): The Forgotten Scholar: Georg Zoëga (1755-1809), Leiden 2015, 15-24 (især 17).

9 Welcker: Zoegas Leben, II, 440-442. De nævnte illustrationer findes i dag i Thorvaldsens Museum, inv. nr. D1217-D1514, E1426, E1428, E1401-E1415.

10 Thorvaldsens Museum, inv. nr. M388, M467, M721.

11 Visconti \& Visconti: Il Museo Pio-Clementino.

12 G. Zoëga: Collectanea et adversaria, nec non opera nonnulla deinceps edita, secundum ordinem catalogi a G. Koesio deligenter confecti, recensita, Håndskriftsafdelingen, KB, NKS 357 b folio. Kasse: VII) Apparatus ad auctoris opus: "Bassirilievi antichi di Roma", continens descriptiones Anaglyphorum tam Rome quam in aliis Italice regionibus exstantium, et que ad horum monumentorum illustrationem pertinere videantur. Ark mærket '461'.

13 F.G. Welcker: "Zoegas Bemerkungen über Viscontis Museo Pio-Clementino", i: Zeitschrift für Geschichte und Auslegung der alten Kunst I, 1818, 446-452.

14 G. Zoëga: Li bassirilievi antichi di Roma, I-III, Rom 1808. Det er vigtigt her at understrege, at Zoëga valgte at illustrere sit eget bogværk med de såkaldte konturstik, dvs. et kobberstik med langt færre modellerende skyggevirkninger, end det er tilfældet hos Cunego. Kun de vigtigste linjer gengives. Dette illustrationsvalg hænger nøje sammen med Zoëgas fokus på præcision og færrest mulige tolkninger. Han fokuserede på genstandenes former, motivets komposition og på identifikationen af antikkens formelle billedsprog og konventioner. I sit forord skrev Zoëga netop om linjens vigtighed for opfattelsen 
af det væsentlige i motivet. Både Zoëga - og efterfølgende også Thorvaldsen valgte derfor som en selvfølgelighed det sort-hvide konturstik som den foretrukne illustrationsform.

15 G. Zoëga: Li bassirilievi, I, V-X.

16 G. Zoëga til F. Münter, 20.8.1807, i: Ø. Andreassen, K. Ascani (red.): Georg Zoëga. Briefe und Dokumente, V, 2013, brev nr. 1230. Den omtalte Piroli er den italienske tegner og kobberstikker Tommaso Piroli (ca. 1752-1824).

17 F.G. Welcker: "Zoegas Bemerkungen über Viscontis Museo Pio-Clementino", i: Zeitschrift für Geschichte und Auslegung der alten Kunst I, 1818, 446-452.

18 Der henvises i det følgende til breve i $\mathrm{Ny}$ Carlsberg Glyptoteks arkiv. De er venligt stillet til rådighed af mag.art. Claus Grønne, arkivar ved Ny Carlsbergfondet. Han forbereder for tiden en online-udgivelse af Carl Jacobsens korrespondance.

19 Far til forfatteren Sigrid Undset (18821949).

20 M. Moltesen: Perfect Partners. The Collaboration between Carl Jacobsen and his Agent in Rome Wolfgang Helbig in the Formation of the Ny Carlsberg Glyptotek 1887-1914, 2012.

21 Ny Carlsberg Glyptotek IN 843. J.S. Østergaard: Katalog. Ny Carlsberg Glyptotek. Romersk kejsertid, I, 1996, 96-99, nr. 42.

22 Carl Jacobsen: Glyptotheket på Ny Carlsberg. Vejledning for de besogende, 1883, 25-27, nr. 45. Han udgav den første vejledning i 1882, hvor samlingen blev åbnet for publikum, om søndagen. Nye udgaver og tillæg udkom derefter jævnligt i takt med Glyptotekets vækst. Formuleringen fra 1883 gentages i det første katalog: Carl Jacobsen: Fortegnelse over de antike kunstverker, 1907, 265-267.

23 F. Poulsen: Katalog over antike skulpturer, 1940, 528-530, nr. 778; Catalogue of Ancient Sculpture in the Ny Carlsberg Glyptotek, 1951, 544-546, nr. 788; F. Matz: Die dionysischen Sarkophage, Die antiken Sarkophagreliefs, 4, 2, Berlin 1968, 183-186, nr. 75.

24 Den har inventarnummer 124682. A.L. Pietrogrande: "Sarcofago policromo con rappresentazione Bacchica", i: Bullettino della Commissione Archeologica Comunale di Roma, 60, 1933, 177-216, især 207-215. Jf. M. Sapelli: "I Sarcofagi del Museo Nazionale Romano. Considerazioni su Contesti di Provenienza e dati Tecnici”, i: G. Koch (ed.): Grabeskunst der römischen Kaiserzeit, Mainz, 1993, 224-225, Tf. 98 , $1-2$.

25 J.S. Østergaard (et al.): Katalog. Ny Carlsberg Glyptotek. Romersk kejsertid I, 1996, 96-99, nr. 42.

26 En udstilling om emnet blev vist i museet i 2004: A.M. Nielsen og J.S. Østergaard (red.): ClassiColor. Farven i antik skulptur, 2004.

27 Kirsten og Freddy Johansens Fond (mikroskoper) og Carlsbergfondet. Jf. www.trackingcolour.com. Projektet blev formidlet i en udstilling i museet: J.S. Østergaard og A.M. Nielsen (red.): Som forvandlet. Antik skulptur i farver, 2014.

28 Se www.trackingcolour.com/objects/138. 